Available online at https:/ /jurnal.iainponorogo.ac.id/index.php/eltall

\title{
POLITENESS STRATEGY PERFORMED IN SATU JAM LEBIH DEKAT TALK SHOW ON TV ONE: A PRAGMATIC APPROACH
}

\author{
Nur Aini Syah \\ Institut Agama Islam Negeri Ponorogo \\ nurainisyah2021@gmail.com
}

\begin{abstract}
Talk show program on TV One is a program that uses language as a means of communication. To create the success of cummunication, it needs a strategy. This study aims to find out the politeness srategies used in Satu Jam Lebih Dekat talk show on TV One. The method used in this article is descriptive qualitative method. The data source of this research is oral data source, which is focused on the speeches between the presenter, interviewees, and mystery guest with the sources from a number of ministers in our country by downloading on the site www.youtube.com. For data analysis technique, the researcher used the contextual method with the pragmatic competence-in-dividing. And for the theory, the researcher focuses on politeness strategies by Brown Levinson's theory (1987: 94).The results indicate that there are 16 types of politeness strategies of Satu Jam Lebih Dekat program namely Bald on record, Positive Politeness-attend to hearer, Positive Politeness-intensify interest, Positive Politeness-use group identify marker, Positive Politeness-seek agreement, Positive Politeness-avoid disagreement, Positive Politenessassert speaker's knowledge, Positive Politeness-include both speaker and hearer in activity, Positive Politeness-give or ask reasons, Positive Politeness-give gifts, Negative Politeness-be conventionally indirect, Negative Politeness-question, hedge, Negative Politeness-give deference, Negative Politeness-impersonalize speaker and hearer, Off record-give hints, and Off record-give association clues. The most dominant use of politeness strategy is positive politeness-asking an agreement with the 42 percentage. The politeness strategies of this speech acts support the effectiveness of talk show and will minimize threats, protect, and extract information from interviewees without any compulsion due to the use of this politeness strategy.
\end{abstract}

Keywords: pragmatics, politeness strategy, talk show

\section{INTRODUCTION}

As a means of communication and interaction, language has very important role in human life. Humans use language to convey their messages to their listeners. In conveying their message, it needs cooperation. The harmony of the relationship between the speaker and the interlocutor can be maintained if each participant is always polite and respects one another. According to the Leech 
(2011: 121) he argues that the principle of politeness is as a necessary principle, which avoid from serious difficulties. Therefore, the principle of politeness is needed to build a good relationship between speakers and listeners (Grice, 1989: 26-27).

Research using pragmatic reviews, especially language politeness, was conducted by Nurhayati (2010) with the title "Realization of Language Teaching in the Ronggeng Dukuh Paruk Novel by Ahmad Tohari". This research discusses speech acts and the realization of language politeness. This research tends to lead to the types of speech acts and the realization of language politeness in a novel.

Furthermore, Hasibuan's (2005) in his reserach entitled "Perangkat Tindak Tutur dan Siasat Kesantunan Berbahasa (Data Bahasa Mandaling (Mandaling Language Data)" discusses the existence of illocutionary power in speech acts by combining linguistic knowledge with a background in cultural knowledge and understanding of the context when speaking.

Then Rahadini, A.A and Suwaro (2014) with the title "Kesantunan Berbahasa dalam Interaksi Pembelajaran Bahasa Jawa di SMP N I Banyumas" discuss the form of language politeness of teachers and students in Javanese language learning interactions at SMP N 1 Banyumas which is seen from the contents of the speech of teachers and students who adhere to the principles of wisdom, the principles of formality-tepa selira, the principles of respect and humility-andhap asor.

Research using other language politeness was conducted by Alviah, Iin (2014) with the title "Kesantunan Berbahasa dalam Tuturan Novel Para Priyayi Karya Umar Kayam". In her research, she discusses the types of illocutionary speech acts, and the characteristics of the speech used to create language politeness.

From the results of previous study before, they generally discuss about politeness which is used to review programs on television, internet, novels, emails, as well as in occupations such as teachers, students, students university, lecturers, sellers, and buyers. From the previous study, it helped researchers to get the opportunity to take research on politeness but using different object that is in a television program, namely a talk show.

This study has similarities with previous studies, that is about language politeness. The difference is in the object of research, and also this study does not discuss the whole speech act, but this research focuses on politeness strategies using Brown Levinson's theory (1987: 94).

The object chosen in this study was the Talk Show "Satu Jam Lebih Dekat (SJLD) on TV One". The SJLD talk show was chosen as the object of research because: the SJLD talk show program provided many inspirations to the audience which discusses about human interest, family, career, hobbies, and their personal life. 
About the theme of this talk show, This talk show has a narrower theme. This program only focuses on discussing one character in depth to touch his humanist side. The humanist side raised is reflected in the difficult career struggles of the speakers and many challenges of them. And the most important is we can gain valuable lessons from all the history of its figures.

In this study, the researchers focused on the speeches between the presenter, interviewees, and mystery guest with the sources from a number of ministers in our country.

The number of ministers appointed in this study were (1) Dr. Rizal Ramly, Minister of Maritime Affairs broadcast on January 1, 2016, (2) Retno Marsudi, Minister of Foreign Affairs aired on January 8, 2016, (3) Tjahjo Kumolo, Minister of Home Affairs aired on February 12, 2016, (4) Dr. Yuddy Crisnadi, M.S Minister of Apparatus and State Apparatus Empowerment broadcast on February 19, 2016, and (5) Khofifah Indar Parawansa, Minister of Social Affairs broadcast on May 3, 2016.

This research is a research related to the use of language as communication between the presenter, interviewees or motivator and mystery guest. This study uses pragmatic theory as an overview because in the conversation between the presenter, interviewees and mystery guest, there are many language relationships with the external elements of language as a characteristic of pragmatics. It is as stated by Searle (1976: 16) that the production or expenditure of a sentence under certain conditions is a speech act, and speech act is the minimum linguistic unit of communication, the speech act is the most important thing in pragmatic studies.

Futhermore, this research uses politeness strategies performed in Satu Jam Lebih Dekat talk show with some reasons, (1) a person's politeness is judged by his ability to explore the potential of his language and its properly and correctly (2) polite language will facilitate the delivery of messages in communication and (3) language that is less polite can hurt the feelings of others so it often creates new conflicts in communication.

Politeness here is associated with the concept of "face" which is followed by various politeness strategies that aim to minimize the threat of the face, which is better known as the FTA or the Face Threatening Act (Brown Levinson, 1987: 68). This theory is famous with the four politeness strategies, namely (1) direct politeness (bald on record), (2) negative politeness, (3) positive politeness, and (4) indirect politeness or off record (Brown Levinson, 1987 : 68). This politeness strategies by Brown Levinson, is expected to be able to support the effectiveness of Satu Jam Lebih Dekat talk show on TV One.

\section{METHODS}

This research uses descriptive qualitative with the aim of case study (Subroto, 1992: 7). It means the researcher records carefully and takes the data in the form of words, sentences, discourses, pictures or photos, diaries, memoranda, videos and types. The purpose of this research is to understand and describe cultural phenomena that are hidden or little known to people (Santosa, 2014: 27). 
This research also uses pragmatic. It means, this study is based on reactions or responses from the interlocutor or listeners (Subroto, 1992: 61). The data sources of this research is taken from oral data sources in the form of speeches between presenters, interviewees and mistery guest which contain of directive speech acts and their politeness strategies whichs airs on January until May 2016.

In addition, this study also uses purposive sampling technique based on certain considerations in accordance with the objectives. The purposive sampling here is based on criteria, including: (1) Host, (2) Resource persons or interviewees, (3) Mistery guest who interacts directly with the speakers, and (4) politeness strategies in Satu Jam Lebih Dekat Talk Show, on January to May 2016. The method of this data collection is inductive. It means that the data is collected one by one then it will be analyzed (Santosa, 2014: 29). The data that is collected gradually will become large and adjusted for the purposes of this study

And the last, for the data analysis uses contextual analysis method. According to Rahardi (2005: 16), the contextual analysis method is a method of analysis that is applied to the data by basing, calculating, and relating the identity of the existing of that contexts.

\section{FINDINGS AND DISCUSSIONS}

Politeness is closely related to the concept of 'face' or in English it is called the concept of a face. The concept of face or face refers to the opinion of Goffman quoted by Brown \& Levinson (1987: 61) that the face is the self-image, reputation, or self-esteem of someone who is emotionally emotional by someone. That face can be lost, it can be preserved or saved, increased and must be uprooted.

The politeness strategy in this research has important thing as way of the speaker to make his speech polite and appreciated. In this regard, the following is a discussion of politeness strategies of illocutionary speech act in Satu Jam Lebih Dekat talk show on TV One.

Table 1: The Politeness Strategy of Satu Jam

Lebih Dekat Talk Show

\begin{tabular}{|l|l|l|l|}
\hline \multicolumn{1}{|c|}{ No } & \multicolumn{1}{|c|}{ Politeness Strategies } & \multicolumn{1}{|c|}{ Amount } & Percentage \\
\hline 1. & Bald on record & 20 & $2,2 \%$ \\
\hline 2. & Positive Politeness-attend to hearer & 8 & $0,9 \%$ \\
\hline 3. & Positive Politeness-intensify interest & 50 & $5,4 \%$ \\
\hline 4. & Positive Politeness-use group identify & 98 & $10,6 \%$ \\
\hline
\end{tabular}


BL'TAL, (ENGLISH JANGUAGE 'TEACHING, APPIIED IINGUIS'IICS

ANI LI'TRRA'T'URE)

Vol. 2 No. 1, 2021

Available online at https:/ /jurnal.iainponorogo.ac.id/index.php/eltall

\begin{tabular}{|l|l|l|l|}
\hline & marker & & \\
\hline 5. & Positive Politeness-seek agreement & 389 & $42 \%$ \\
\hline 6. & Positive Politeness-avoid disagreement & 37 & $4 \%$ \\
\hline 7. & $\begin{array}{l}\text { Positive Politeness-assert speaker's } \\
\text { knowledge }\end{array}$ & 23 & $2,5 \%$ \\
\hline 8. & $\begin{array}{l}\text { Positive Politeness-include both speaker } \\
\text { and hearer in activity }\end{array}$ & 15 & $1,6 \%$ \\
\hline 9. & Positive Politeness-give or ask reasons & 109 & $11,7 \%$ \\
\hline 10. & Positive Politeness-give gifts & 13 & $1,4 \%$ \\
\hline 11. & $\begin{array}{l}\text { Negative Politeness-be conventionally } \\
\text { indirect }\end{array}$ & 3 & $0,3 \%$ \\
\hline 12. & Negative Politeness-question, hedge & 1 & $0,1 \%$ \\
\hline 13. & Negative Politeness-give deference & 19 & $2 \%$ \\
\hline 14. & $\begin{array}{l}\text { Negative Politeness-impersonalize } \\
\text { speaker and } \\
\text { hearer }\end{array}$ & 1 & $0,1 \%$ \\
\hline 15. & Off record-give hints & 89 & $9,6 \%$ \\
\hline 16. & Off record-give association clues & 53 & $5,7 \%$ \\
\hline Total & 928 & $100 \%$ & \\
\hline & 928 & \\
\hline
\end{tabular}

Table 1 shows the realization of politeness strategy of directive speech act in Satu Jam Lebih Dekat Talk Show. The most frequent of politeness strategy used in Satu Jam Lebih Dekat Talk Show is Positive Politeness-seek agreement. The data analysis based on the classification of table 1 as follow:

\section{The Realization of Politeness Strategy}

\section{a) Direct Politeness (Bald On-record)}

Direct strategy is a strategy of politeness that is used when the speaker's wishes to do face threatening act in maximum efficiency exceeds the hearer's 
BLTALL (ENGLISH IANGUAGE 'TEACHING, APPLIED IINGUIS'TICS

ANI LI'TIRA'TURE)

Vol. 2 No. 1, 2021

Available online at https:/ /jurnal.iainponorogo.ac.id/index.php/eltall

desire (Brown and Levinson, 1987: 94- 95). The data indicate a direct politeness strategies (Bald On-record) can be seen in the following data.

\section{(1) The context of the speech:}

The conversation took place between Indy Rahmawati (host) and Tjahyo Kumolo (speakers). Indy Rahmawati asks where a place to put his guitar? Then Mr Tjahyo Kumolo ordered to put the guitar near his seat.

\section{Forms of speech:}

Indy Rahmawati : Okay, it was already mention some group including Koes plus group. Can I put that guitar? Where I should go? 153)

Tjahyo Kumolo : $\quad$ Put it there! (154)

Indy Rahmawati : Put it okey

(154/SJLD-TK/ TTD type-commanding /12 Februari 2016)

In the conversation number (154) there is a direct politeness strategy (bald on record). Direct politeness strategy used to refer to the speaker's wishes to do face threatening act in maximum efficiency exceeds the hearer's desire. It is deliver by Mr Tjahyo Kumolo with the sentences "Put it there!". It is as the lingual marker of their politeness strategies (bald on record).

\section{b) Positive Politeness-use group identify marker}

Positive politeness is directly aimed at the hearer's positive face (Brown and Levinson, 1987:101). The data indicate a positive politeness-use group identify marker can be seen in the following data.

\section{(2) Context of speech:}

The conversation took place between Indy Rahmawati (host) with Rizal Ramli (speakers). Indy Rahmawati shows enclosed photo. Indy asks Mr. Rizal to guess whose picture and how the stories happened.

\section{Forms of speech:}

Indy $\quad$ : $\quad$ There should be seen $\mathbf{M r}$, on this view. (046) This Rahmawati is a picture guest it! (047)

Indy $\quad$ : look back if can't seen! (050) already imagine in Rahmawati your mind Sir? (051) 
In conversation the data (051) are positive Politeness -using a marker of group identity. This shows that the hearer desire of politeness regarded as something that is also wanted by the speaker, what is desired by the hearer is also something to be desired by the speakers. It is showen in the speech data is (051) submitted by Indy Rahmawati "already imagine Mr? (051). The word 'sir' is a marker of group identity of married man. This speech included in TTD type 'asking'.

\section{c) Positive Politeness -seek agreement}

Positive politeness is aimed at the hearer positive face (Brown and Levinson, 1987: 101). The data indicate a positive politeness-use group identify marker can be seen in the following data.

(3)The context of speech: The conversation took place between Indy Rahmawati (host) with Tjahyo Kumolo (speakers) and also Yon Koeswoyo. Indy Rahmawati inquire and praised the meeting with idol is like a dream.

\section{Forms of speech:}

Indy Rahmawati : $\quad$ Back to Mr Tjahyo this meeting like a dream or not? (169) just said before that this meeting just like a dream, this meeting like a dream? (170)

Tjahyo Kumolo : $\quad$ last time I hunt for tickets Indy Rahmawati : $\quad$ And watch the idol, right? (171)

Tjahyo Kumolo : $\quad$ until Histora at the last time

(169/SJLD-TK/TTD type-asking/12 Februari 2016)

(171/SJLD-TK/TTD type-asking/12 Februari 2016)

In conversation the data (169) and (171) are positive Politeness -looking approval. This shows that the desire of hearer regarded as something that is also wanted by the speaker. It is delivered by Indy Rahmawati "and watch the idol, right? (171)". Its speech became a lingual marker of positive politeness strategy seeking approval. The word "right?" is a marker of seeking approval. This speech includes TTD type-asking. 
BLTALL (ENGLISH IANGUAGE 'TEACHING, APPLIED IINGUIS'TICS

AND II'TIRA'TURI)

Vol. 2 No. 1, 2021

Available online at https:/ /jurnal.iainponorogo.ac.id/index.php/eltall

\section{d) Positive Politeness-Ask Reason}

Positive politeness is directly aimed at the positive hearer face (Brown and Levinson, 1987:101). The data indicate the positive politeness strategy ask the reason can be seen in the following data.

\section{(4) The context of speech:}

The conversation took place between Indy Rahmawati (host) with Tjahyo Kumolo (speakers). Indy Rahmawati ask about the tiger statues. Then Indy asked about who is waiting and keeping the statues. Indy also ask why the number of statue should be five.

\section{Forms of speech:}

Indy Rahmawati : $\quad$ On the back is also still there, get into the middle of the room there's a tiger, tiger statues. (130) Is there a story Mr Tjahyo Kumolo? (131)

Tjahyo Kumolo : $\quad$ Well if the tiger was indeed from the process I put some historic objects treasure together.

Indy Rahmawati : Then, who keep this thing? Who is? (132)

Tjahyo Kumolo : : Waiting for what it meant? (135)

Indy Rahmawati : $\quad$ Awaiting these things meant.

Indy Rahmawati : $\quad$ Why should even 5? (139)

Tjahyo Kumolo : : Just five only

(132/SJLD-TK/TTD type-asking/12 Februari 2016)

(135/SJLD-TK/TTD type-asking/12 Februari 2016)

In conversation the data (132) and data (135) contained Positive Politeness leave questions or ask for a reason. This politeness shows that the desire of speakers to provide questions or ask forreasons to hearer. It is delivered by Indy Rahmawati "then, who keep this thing? Who is? (132) (132)". Conversations (132) these speakers provide questions to the hearer with the aim to provide advice indirectly to the hearer. Suggestions in question are to find a place to store these statues. Suggestions indirect form of the question is what a form of positive politeness is. The data (135) as submitted by Indy Rahmawati is "Why should even 5?" This speech also contains the intention of seeking reasons as well as providing advice indirectly. Utterances (132) and (135) included in the TTD type-'ask'.

In this talk show, the speakers fulfill politeness strategies by implementing these strategies. The form of strategic markers of positive politeness such as the word "wow surprise". It means, the speakers pay the attention to the preferences.Then, the form of positive politeness strategy -group identity marker 
is shown by using the word "sir, mom, friend". A marker for positive politeness strategies-seeking approval is by using the word "no?, yes?, right?". Then, the form of positive politeness strategy marker - avoids disagreement by using the word "may". They also use the word "we" to mark the lingual marker of positive politeness strategies-involving speech partners in activities. And the lingual marker of negative politeness strategies - by using hedging sentences the word "I think".

This talk show also contains motivation, advice, and invitations. So, the use of politeness stratey is very necessary in this conversation, in order to make comfortable in communication, conveying information, motivation, advice or life teachings.

The use of this politeness strategy will make this talk show effective, they will minimize face threats and will protect each other's faces. Speakers also can extract information from interviewees without any compulsion due to the use of this politeness strategy. Therefore, this politeness strategy is able to support the effectiveness of the Satu Jam Lebih Dekat talk show on TV One.

\section{CONCLUSIONS AND SUGGESTION}

Based on the data classification and analysis, the politeness strategy in the directive speech act of Satu Jam Lebih Dekat Talk Show are bald on record, positive politenessattend to hearer his interest, wants, needs, and goods, positive politeness intensify interest to hearer, positive politeness-use in group identity markers, positive politeness-seek agreement, positive politeness-avoid disagreement, positive politeness-assert or presuppose speaker's knowledge and concern for hearer's want, positive politeness-include both speaker and hearer in the activity, positive politeness-give or ask for reasons, positive politeness-give gifts to hearer, negative politeness-be conventionally indirect, negative politenessquestion, hedge, negative politeness-give deference, negative politenessimpersonalize speaker and hearer, off record-give hints, and negative politeness give association clues. The most dominant use of politeness strategy is positive politeness-asking an agreement.

The politeness of directive speech acts supports the effectiveness of talk show because of some factors which is influence such as sub-directive speech act to please, to request, to ask, to order, to invite, to forbid, convincing, to obligate, to show, to give, to hope, to want, to warn, to advise, to request, and to permit. The other factor is the use of some politeness strategies which minimalize face threatening act. The use of sub-directive speech act, politeness principle, and 
politeness strategies support the effectiveness of talk show from the receiver, the content, the time, media, form, source, cognitive, affective and conative effect.

Some limitations for this study related to the topic discussed in this article are as follow: (1) this article only focuses on the use of politeness strategies. Thus, for the future study, it can study the speech act as a whole aspect, (2). This research studies the speech act of Satu Jam Lebih Dekat talk show from pragmatic point of view. In the future, it is suggested that it can be studied by focusing on its style of language.

\section{REFERENCES}

Brown, P., dan Levinson, S. (1987). Politeness Some Universals in Language Usage. Cambridge:Cambridge University Press.

Fotouhi, F., dan Ziyaei, F. (2015). The Role of Politeness Strategies in Writing Emails. Iran: Indian Journal of Fundamental and Applied Life Scieces, vol. 5, no. 1, hlm 5294-5298.

Gil, J.M. (2012). Face-Threatening Speech Act and Face-Invading Speech Act: An Interpretation of Politeness Phenomena. Argentina: International Journal of Linguistics, vol. 4, no.2, hlm 400-411.

Grice, H.P. (1989). Studies in The Way of Words. England: Harvard University Press.

Gunarwan, Asim. (2007). Implikatur dan Kesantunan Berbahasa: Tindak Tutur dan Kesantunan Berbahasa: Beberapa Tilikan Sandiwara Ludruk dalam Yassir Nasanius (Peny). PELLBA 18. Jakarta: Pusat Kajian Bahasa Dan Buadya Unika Atma Jaya.

Leech, Geoffrey. (2011). Prinsip-Prinsip Pragmatik (Terjemahan oleh M.D.D Oka). Jakarta: UI Press.

(2015). Prinsip-Prinsip Pragmatik (Terjemahan oleh M.D.D Oka). Jakarta: UI Press.

Mahsun. (2012). Metode Penelitian Bahasa. Jakarta: PT Raja Grafindo Persada.

Moleong, Lexy J. 2015. Metodologi Penelitian Kualitatif. Bandung: PT Remaja Rosdakarya.

Rahardi, Kunjana. (2005). Pragmatik: Kesantunan Imperatif Bahasa Indonesia. Jakarta: Erlangga 
BLTALL (ENGLISH IANGUAGE 'TEACHING, APPLIED IINGUIS'TICS

AND II'TIRA'TURI)

Vol. 2 No. 1, 2021

Available online at https:/ /jurnal.iainponorogo.ac.id/index.php/eltall

.(2009). Sosiopragmatik Kajian Imperatif dalam Wadah Sosiokultural dan Konteks Situasionalnya. Jakarta: Penerbit Erlangga.

Santosa, Riyadi. (2014). Metode Penelitian Kualitatif Kebahasaan. Surakarta: Universitas Sebelas Maret

Searle, J.R. (1969). Speech Act An Essay in the Philosophy of Language. Cambridge: Cambridge University Press.

(1985). Foundations of Illocutionary Logic. Cambridge: Cambridge University Press.

Spradley, James P. (2007). Metodologi Etnografi. Yogyakarta: Tiara Wacana

Sudaryanto. (1993). Metode dan Aneka Teknik Analisis Bahasa: Pengantar Penelitian Wahana Kebudayaan Secara Linguistik. Yogyakarta: Duta Wacana University Press.

Sulaiman, M., dan Khoshaba, L. (2016). Speech Act as a Basic of Understanding Dialogue Coherence with Reference to Engish-Arabic Translation. Macedonia: International Jurnal of Social Science and Humanities, vol. 1, no. 1, hlm 68-98

Timberg, Bernard. (2004). Television A History of The TV Talk show. USA: University of Texas Press

Tripp, S.E., Guo, J., dan Lampert, M. (1990). Politeness and Persuasion in Children's Control Acts. North-Holland: Journal of Pragmatic, vol. 14, hlm 307-331.

Yule, George. (1996). Pragmatics. Oxford: Oxford University Press

Yuliana, R., Rohmadi, M., dan Suhita, R. (2013). Daya Pragmatik Tindak Tutur Dalam Pembelajaran Bahasa Indonesia pada Siswa Sekolah Menengah Pertama, Basastra: Jurnal Penelitian Bahasa, Sastra Indonesia dan Pengajaranya, vol. 2, no. 1, hlm 1-14.

Zhao, Y., dan Throssell, P. (2011). Speech Act Theory and Its Application to EFL Teaching in China. Tasmania: The International Journal-Language Society and Culture, issue. 32, hlm 88-95. 